ISSN 2414-1143

Научный альманах стран Причерноморья. 2018. Том 13. № 1

DOI 10.23947/2414-1143-2018-13-1-60-77

UDC 57

\title{
THREE STAGE BIOTECHNOLOGY FOR THE REHABILITATION OF SOILS POLLUTED WITH EXPLOSIVES
}

\author{
(c) Giorgi Kvesitadze, Besarion Ch. Meskhi, Gia Khatisashvili
}

\author{
Georgian National Academy of Sciences \\ Don state technical university \\ Agricultural University of Georgia \\ science-almanac@mail.ru
}

\begin{abstract}
Widespread contamination of the environment by explosives due to the manufacture, disposal and testing of munitions has become a major international concern connected with the increasing scale of soil and ground water contamination. Most explosives are considered to be a major hazard to the biological system due to their high toxicity and mutagenic effects. Research on biotransformation of explosives has clearly shown that some plants and several families of aerobic microorganisms, representing different taxonomic groups of microorganisms, have the potential to transform TNT (2,4,6-trinitrotoluene), RDX (hexogen - hexahydro-1,3,5-trinitro-1,3,5triazine) and other nitro organic explosives to non toxic products. Despite the existence of such extensive data, there is no reliable information dealing with the affordable clean up technology of explosives. To evaluate the disappearance of TNT and its intermediate products, in the last decade, great attention has been paid to microorganisms (both eukaryotes and prokaryotes) and plants. Microorganisms being well established detoxifiers, of structurally varying contaminants, are promising natural tools that allows to sustain the ecological balance. The ability of plants to cleanup the environment has still attracted relatively little attention, having no long story. Although plants play an important role in sustaining and restoring all niches of the environment due to their ability to absorb and metabolize quite a wide spectrum of various contaminants of organic nature, plants for cleanup the environment has attracted relatively little attention having no long story. Research carried out for more than 30 years, with annual and perennial plants and various families of different taxonomic groups of microorganisms have revealed their potential to absorb and metabolize organic contaminants of different structure. Three laboratories, at Durmishidze Institute of Biochemistry and Biotechnology (Georgia) have carried out research aimed at the creation of a new biotechnological approach for rehabilitation of soils polluted with explosives based on joint, symbiotic action of microorganisms and plants.
\end{abstract}

Key words: biotechnology, rehabilitation, soils, explosives, TNT, RDX, microorganisms and plants.

\section{[Г. Квеситадзе, Б. Месхи, Г. Хатисашвили Три стадии биотехнологий для восстановления почвы, загрязненной от взрывчатых веществ]}

Широкое загрязнение окружающей среды взрывчатыми веществами из-за производства, утилизации и испытания боеприпасов стало серьезной международной проблемой, связанной с увеличением масштабов загрязнения почвы и подземных вод. Большинство взрывчатых веществ считаются серьезной угрозой для биологической системы из-за их высокой токсичности и мутагенных эффеектов. Исследования по биотрансформации взрывчатых веществ ясно показали, что некоторые растения и несколько семейств аэробных микроорганизмов, представляющих различные таксономические группы микроорганизмов, могут трансформировать TNT (2,4,6-тринитротолуол), RDX (гексоген-гексагидро-1,3, 5-тринитро1,3,5-триазин) и другие нитроорганические взрывчатые вещества для нетоксичных продуктов. Несмотря на наличие таких обширных данных, нет надежной информации, касающейся доступной технологии очистки взрывчатых веществ. Чтобы оценить исчезновение TNT и его промежуточных продуктов, в последнее десятилетие большое внимание уделялось микроорганизмам (как эукариот, так и прокариотам) и растениям. Микроорганизмы, являющиеся хорошо установленными детоксификаторами, структурно изменяющихся загрязнителей, являются перспективными природными инструментами, которые позволяют поддерживать экологический баланс. Способность растений к очистке окружающей среды все еще привлекает относительно мало внимания. Растения играют важную роль в поддержании и восстановлении всех ниш окружающей среды из-за их способности поглощать и метаболизировать довольно широ- 
кий спектр различных загрязняющих веществ органической природы. Исследования, проведенные более 30 лет с ежегодными и многолетними растениями и различными семействами различных таксономических групп микроорганизмов, показали их потенциал для поглощения и метаболизма органических загрязнителей различной структуры. Три лаборатории в Институте биохимии и биотехнологии им. Дурмишидзе (Грузия) провели исследования, направленные на создание нового биотехнологического подхода для реабилитации загрязненных взрывчаткой почв на основе совместного, симбиотического действия микроорганизмов и растений.

Ключевые слова: биотехнологии, восстановление, почва, взрывчатые вещества, TNT, RDX, микроорганизмы и растения.

Giorgi Kvesitadze - Ph.D. of biology, professor, president of Georgia national academy of sciences. Tbilisi, Georgia.

Besarion Ch. Meskhi - Ph.D of technical studies, professor. Rector of Don state technical university. Rostov-onDon, Russian Federation

Gia Khatisashvili - Ph.D. of biological sciences, professor. Agricultural university of Georgia. Tbilisi, Georgia.

Квеситадзе Гиорги - доктор биологических наук, профрессор, президент Национальной академии наук Грузии. Тбилиси, Грузия.

Месхи Бесарион Чохоевич - доктор технических наук, профрессор. Ректор Донского государственного технического университета. Ростов-на-Дону, Россия.

Хатисашвили Гия - доктор биологических наук, профессор. Университет сельского хозяйства Грузии. Тбилиси, Грузия.

Materials and methods: Plants

Experiments were carried out with the following annual mono and dicotyledonous plants: ryegrass (Lolium multiflorum), maize (Zea mays), chickling vetch (Lathyrus sativum), chickpea (Cicer arietinum), alfalfa (Medicago sativa), china bean (Vigna sinensis), mung bean (Vigna radiata), and soybean (Glycine max).

Effect of Explosives on Seed Germination and Plant Growth

Plant seeds were soaked in running water or solutions containing different concentrations of TNT $(0.1,0.5$ and $1.0 \mathrm{mM})$ and $\operatorname{RDX}(0.10,0.25,0.50,1,0$ and $2.5 \mathrm{mM})$, at temperature $22-25^{\circ} \mathrm{C}$. After 4 days of seeds germination, i.e. the correlation between the number of germinated and sowed seeds was estimated. The germinated seedlings were exposed to different concentrations of TNT or RDX solutions in tap water and cultivated hydroponically at ambient illumination and temperature $\left(22-25^{\circ} \mathrm{C}\right)$. Plant growth parameters: plant biomass, height of stems, length of roots and chlorophyll content have been determined daily, during 10 days.

\section{Microorganisms Growth}

To screen active strains of microorganisms on their capability to degrade TNT and RDX, strains of bacteria, fungi, yeasts and actinobacteria from the collections of microorganisms (kept at the Durmishidze Institute of Biochemistry and Biotechnology) have been tested. The diversity of the strains is stipulated due to the fact that microorganisms have been isolated from different soil zones of the country, including polluted soils from military proving grounds [1].

The capability of microorganisms to absorb and degrade organic contaminants was revealed by strains growth on solid agar or on liquid media containing explosives in a shaker at $180 \mathrm{rpm}$ and $28-30^{\circ} \mathrm{C}$. Microorganisms were cultivated in modified Czapek's medium, containing (g/l): $\mathrm{NaNO}_{3}-0.91 ; \mathrm{KH}_{2} \mathrm{PO}_{4}-0.1: \mathrm{MgSO}_{4} \cdot 7 \mathrm{H}_{2} \mathrm{O}-0.05 ; \mathrm{KCl}-0.05 ; \mathrm{FeSO}_{4} \cdot 7 \mathrm{H}_{2} \mathrm{O}-$ 0.02 . In some special cases, glucose $(60 \mathrm{~g} / \mathrm{l})$, or TNT $(0.1,0.2$ or $0.5 \mathrm{mM})$, or RDX $(0.25 \mathrm{or}$ $0.5 \mathrm{mM}$ ) were used as a sole source of carbon. Microorganisms grown up to the exponential 
phase were used as inoculums. The nutrient media were inoculated with suspension (10\% of total broth volume) of microorganisms. The intensity of growth was estimated visually according to the following point scale: - no growth, + weak growth, ++ normal growth, +++ intensive growth, ++++ highly intensive growth.

Preparation of soil polluted with $\left[1-{ }^{14} \mathrm{C}\right] \mathrm{TNT}$

Diethyl ether solution $\left(0.5 \mathrm{~L}\right.$ ) containing $1.05 \mathrm{~g}$ of $\left[1-^{14} \mathrm{C}\right] \mathrm{TNT}$ (specific radioactivity of 500 $\mathrm{Bq} / \mathrm{mg}$ ) was added to air-dried soil $(7 \mathrm{~kg})$ and then the soil was thoroughly mixed. The ether evaporated during 2 days. The suspension of microorganisms was added to the soil samples. Thereafter the soil was placed in special boxes for experiments and the plant seeds were sowed in samples ( 80 seeds on $7 \mathrm{~kg}$ of soil).

To determine the radioactivity of soil samples, residual TNT and its metabolites were extracted by methanol. Methanol extracts were evaporated and dry residue was dissolved in 5 $\mathrm{ml}$ of benzene. One $\mathrm{ml}$ of benzene solution was taken for measurement, on the scintillation spectrometer SL-30 Rackbeta, with an efficiency of $95 \%$.

Model experiments for cleaning water polluted with $\left[1-{ }^{14} \mathrm{C}\right] \mathrm{TNT}$

At the beginning of experiments the water (volume $2 \mathrm{~L}$ ) containing $0.1 \mathrm{mM}\left[1-{ }^{14} \mathrm{C}\right] \mathrm{TNT}$ (specific radioactivity - $500 \mathrm{~Bq} / \mathrm{mg}$ ) was equally distributed in 20 flasks, in which bacterial strains Pseudomonas sp. TNT-44 and Rhodococcus sp. TNT-74 were cultivated. Incubation of polluted water with bacterial consortium was carried out for 3 days in shaken flasks, at shaking speed of $180 \mathrm{rpm}$ and temperature of $28-30^{\circ} \mathrm{C}$. After incubation the contents of flasks were united, heated up to $100^{\circ} \mathrm{C}$ and filtered. The received solution was filled up with tap water to a $6 \mathrm{~L}$ volume and the container subsequently was filled with this solution. Plate with seedlings of soybean was placed in the container.

The container with the polluted water and the plants were placed in the hermetic chamber, with a magnetic mixer. Experiments were carried out at temperature of $20-25^{\circ} \mathrm{C}$, in the dark, for prevention of re-fixation of the released radioactive $\mathrm{CO}_{2}$ by plants. For fixation of released ${ }^{14} \mathrm{CO}_{2}$ in the chamber, a solution with $30 \% \mathrm{KOH}$ was placed in the chamber. Periodically, the radioactivity of polluted water, alkaline solution, and residual amount of TNT in polluted water were measured. At the end of experiments the roots of plants were carefully and repeatedly washed, and the biomass was dried for further application.

Bioutilization of plants used in phytoremediation process

In $1500 \mathrm{ml}$ of Czapek's medium, (g/l): $\mathrm{NaNO}_{3}-0.91 ; \mathrm{KH}_{2} \mathrm{PO}_{4}-0.1 ; \mathrm{MgSO}_{4} \cdot 7 \mathrm{H}_{2} \mathrm{O}-$ $\left.0.05 ; \mathrm{KCl}-0.05 ; \mathrm{FeSO}_{4} \cdot 7 \mathrm{H}_{2} \mathrm{O}-0.02\right) 36.5 \mathrm{~g}$ of soybean biomass was added with radioactivity $178000 \mathrm{~Bq}$.

The cultivation of microscopic fungi with soybean biomass was carried out in a hermetic chamber, on a magnetic mixer at ambient temperature of $20-25^{\circ} \mathrm{C}$, in the dark, to prevent reification of released radioactive $\mathrm{CO}_{2}$ by plant. For the fixation of released ${ }^{14} \mathrm{CO}_{2}$, a glass with $30 \%$ solution of $\mathrm{KOH}$ was placed in the chamber.

Quantitative determination of TNT and RDX

To determine the amount of explosive left in TNT-containing media (water solution), $1 \mathrm{ml}$ of a solution was added to $1 \mathrm{ml}$ of $1 \mathrm{M}$ of $\mathrm{KOH}$. TNT content was determined according to the difference of extinction at $447 \mathrm{~nm}$ [1]. In case of RDX, the analyses were carried out by reverse phase on HPLC [2].

Thin-layer chromatographic (TLC) analysis was carried out on methanol extracts from polluted $\left[1-{ }^{14} \mathrm{C}\right]$ TNT soil samples. TCL-plates were developed with a mixture of benzene : dioxane : acetic acid (90:10:1). The chromatograms were exposed on X-ray film for 45 days to identify radioactive spots. After exposition the radioactive spots were extracted from chromatograms by benzene and their radioactivity was measured.

Determination of Enzymes Activities 
Nitroreductase activity was determined according to the rate of TNT reduction by measuring untransformed TNT in an incubation mixture [1]. In highly alkaline solution, TNT has absorption at $447 \mathrm{~nm}$, whereas its major metabolites: 2-amino-4,6-dinitrotoluene, 4-amino-2,6dinitrotoluene, and 2,6-diamino-4-nitrotoluene, has no absorbance at this wavelength [12]. Peroxidase activity was determined according to the intensity of $\mathrm{H}_{2} \mathrm{O}_{2}$-dependent guaiacol oxidation at 450nm [7]. Phenoloxidase activity was determined by the intensity of catechol oxidation at 420nm [11]. Glutathion S-transferase activity was measured according to rate of oxidation of reduced glutathione [10]. The activity of Cytochrome P450, containing monooxygenase was determined polarographically by determining the oxygen consumption rate of NADPH-dependent oxidation of N,N-dimethylaniline [5]. Protein concentration was measured according to Bradford [13]. Specific activities of enzymes were calculated as mmole transfered substrate in min per mg protein.

Results and Discussion. Plants Growth on Explosives

TNT exposed negative influence on germination of the tested plants seeds: $0.1 \mathrm{mM}$ of TNT on average decreased the number of germinated seeds by $10-15 \%$; at $0.5 \mathrm{mM}$ TNT concentration, the lagging seeds germination was up to $15-25 \%$; at $1 \mathrm{mM}$ TNT concentration, the difference between the germ ability of test and control group variants was equal to $30-40 \%$. As for development of germinated seedlings, much slower growth of the plants was detected when the roots of seedlings were submerged in $0.5 \mathrm{mM}$ solution of TNT (corresponding to 100 ppm pollution level, which exceeds ecological harmless concentration 50 times [9]). Parts of seedlings above the ground lag in growing 2-4 times, as compared with control plants. Accordingly, the plant biomass decreased. The soybean seedlings germinated from the seeds soaked in $0.5 \mathrm{mM}$ solution of TNT, adapt comparatively better to coexistence with explosive. At higher concentration of TNT, equal to $1 \mathrm{mM}$, all plant seedlings have shorter stems; their roots become shorter and brown. This process was accompanied by the significantly decreasing chlorophyll content (25-30\%). High tolerance of soybean to TNT among the tested plants should be mentioned. Growth parameters of this plant decrease only by $5-10 \%$ on saturated solution of the explosive (1.0 mM).

To summarize the data of plants tolerance toward explosives, it can be concluded that the tolerance of 8 tested plants to TNT decreases according in the following order:

\section{Soybean $>$ Mung been $>$ Ryegrass $>$ Chickpea $>$ Chickling vetch $>$ Alfalfa $>$ China bean $>$ Maize}

Statistically valid difference between growth parameters of control and test plants hasn't been obtained in analogous experiments with another explosive - RDX. All the tested plants have practically identical tolerance to increased concentrations of RDX. Moreover, the highest concentration of this explosive $(2.5 \mathrm{mM}$ ), increases formed biomass (by $20 \%$ ) of 10-days old seedlings. Presumably, these plants are able not only to detoxify RDX, but to use this compound as nitrogen and/or carbon source.

Parallel to plant growth, the residual content of TNT in nutrient medium was determined (Fig. 1). The results indicated that TNT uptake of tested legumes decreases in the following order:

\section{Alfalfa $>$ Soybean $>$ Chickpea $>$ Chikling vetch $>$ Mung bean}

It should also be noted that germination of soybean seeds on solution of TNT promotes the assimilation of this explosive by seedlings. Analogous investigations with RDX show that all tested plants completely uptake the explosive from water solutions during 5-7 days (Fig. 2). The seedlings of soybean are characterized with the highest rate of RDX uptake. 


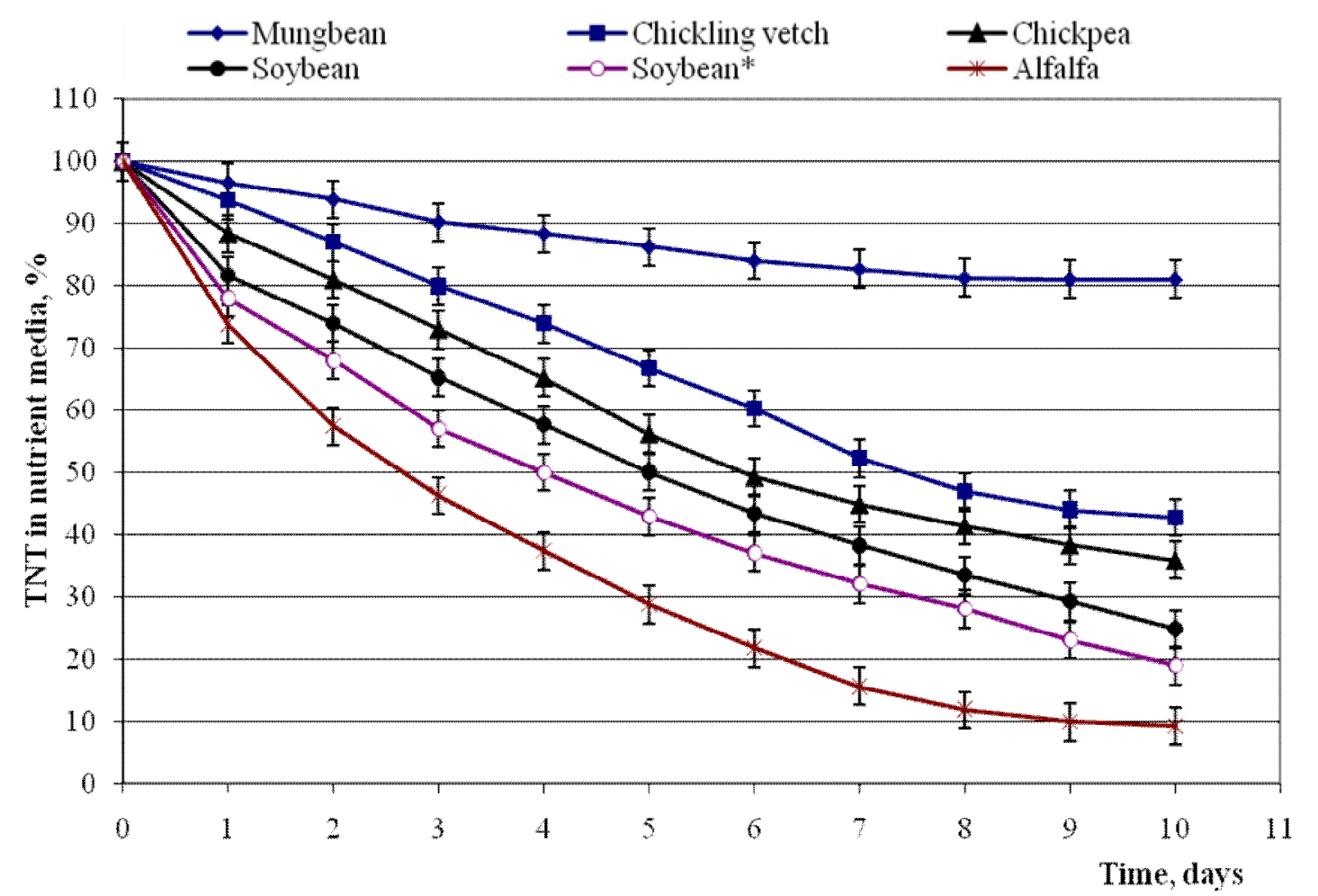

Fig. 1. Uptake of TNT from water solution by plants.

Initial concentration of TNT $-0.5 \mathrm{mM}$. Temperature $22-25^{\circ} \mathrm{C}$.

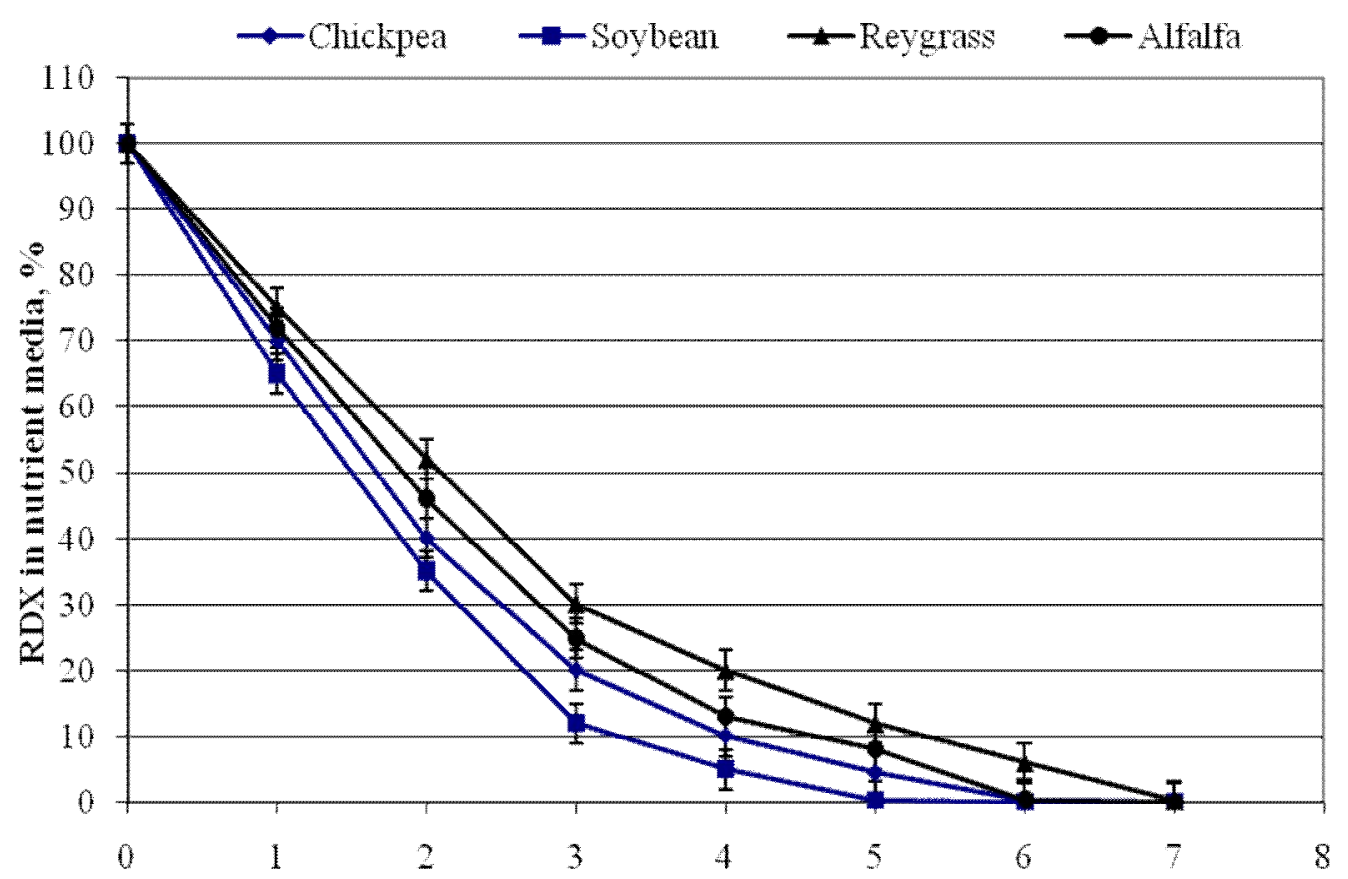

Fig. 2. Uptake of RDX from water solution by plants.

Initial concentration of RDX $-0.5 \mathrm{mM}$. Temperature $22-25^{\circ} \mathrm{C}$.

TNT-nitroreductase activity in plants grown on TNT and RDX containing media has been studied. The results are given in Table 1. 
Table 1.

Effect of nicotinamide coenzyme and ferricyanide on TNT-nitroreductase activity in the homogenate in 14-days alfalfa seedling roots, grown on medium containing TNT $(0.5 \mathrm{mM})$ and RDX (1.0 mM)

\begin{tabular}{|c|c|c|c|}
\hline \multirow{2}{*}{ Incubation medium } & \multicolumn{3}{|c|}{$\begin{array}{c}\text { Rate of TNT-reduction, } \\
\text { nmole/min per mg of protein }\end{array}$} \\
\hline & Control & Induced by TNT & Induced by RDX \\
\hline Homogenate + $50 \mathrm{mM}$ TNT & $6.30 \pm 0.32$ & $10.77 \pm 0.54$ & $9.14 \pm 0.46$ \\
\hline $\begin{array}{l}\text { Homogenate + } 50 \text { mM TNT+ } \\
2 \text { mM NADH }\end{array}$ & $17.07 \pm 0.85$ & $28.33 \pm 1.42$ & $23.89 \pm 1.19$ \\
\hline $\begin{array}{l}\text { Homogenate + } 50 \text { mM TNT+ } \\
2 \text { mM NADPH }\end{array}$ & $21.01 \pm 1.05$ & $36.56 \pm 1.83$ & $29.84 \pm 1.49$ \\
\hline $\begin{array}{l}\text { Homogenate + } 50 \text { mM TNT+ } \\
1 \text { mM NADH + } 1 \text { mM NADPH }\end{array}$ & $18.10 \pm 0.91$ & $30.60 \pm 1.53$ & $26.79 \pm 1.34$ \\
\hline $\begin{array}{l}\text { Homogenate + } 50 \mathrm{mM} \mathrm{TNT+} \\
2 \mathrm{mM} \mathrm{NADH}+ \\
0.1 \mathrm{mM} \mathrm{K}_{3}\left[\mathrm{Fe}(\mathrm{CN})_{6}\right]\end{array}$ & $0.42 \pm 0.02$ & $0.75 \pm 0.04$ & $0.59 \pm 0.03$ \\
\hline $\begin{array}{l}\text { Homogenate }+50 \mathrm{mM} \mathrm{TNT+} \\
2 \mathrm{mM} \mathrm{NADPH}+ \\
0.1 \mathrm{mM} \mathrm{K}_{3}\left[\mathrm{Fe}(\mathrm{CN})_{6}\right]\end{array}$ & $0.48 \pm 0.02$ & $0.86 \pm 0.04$ & $0.72 \pm 0.04$ \\
\hline $\begin{array}{l}\text { Homogenate + } 50 \mathrm{mM} \text { TNT+ } \\
1 \mathrm{mM} \mathrm{NADH}+1 \mathrm{mM} \text { NADPH + } 0.1 \mathrm{mM} \\
\mathrm{K}_{3}\left[\mathrm{Fe}(\mathrm{CN})_{6}\right]\end{array}$ & $0.45 \pm 0.02$ & $0.79 \pm 0.04$ & $0.66 \pm 0.03$ \\
\hline
\end{tabular}

According to the data presented in Table1, in plant roots, TNT-nitroreductase is actively functioning. The enzyme has clearly expressed inducible nature by both substrates: TNT (induction degree 1.7) and RDX (induction degree 1.45). Activity of the enzyme is significantly enhanced by the presence of electron donors NADH and NADPH and does not reveal its specificity towards a concrete nicotinamide coenzyme. It seems that this enzyme corresponds to nonspecific $\mathrm{NAD}(\mathrm{P}) \mathrm{H}$ dependent nitroreductase [2]. Potassium ferricyanide acts as a electron acceptor that (this reagent is used for shunting of reducing equivalents of $N A D(P) H$ Cytochrome $P 450$ reductase) causes inhibition of TNT transformation.

Microorganisms Degrading TNT and RDX

As a result of screening, from 205 bacterial strains: 34 - Pseudomonas, 1 - Bacillus, 8 Rhodococcus and 5 - Mycobacterium strains were selected that had the best growth on solid nutrient medium containing $1 \mathrm{mM}$ TNT. According to the growth intensity on media containing RDX, 8 strains of Pseudomonas and 3 strains of Bacillus were selected. It is interesting to note that some selected bacterial strains, particularly, Pseudomonas sp.3JL3, Pseudomonas sp.R59 and Pseudomonas sp.6Ru57, grew better at high concentration of RDX (1 mM) than at low concentrations.

From the 240 strains collection of microscopic fungi, 14 cultures representing genera Aspergillus, Mortiella, Mucor, Chaetomium, Fusarium, Penicillium, Trichoderma, and Trichotecium actively growing on media containing $0.5 \mathrm{mM}$ TNT and RDX have been selected.

As a result of screening, among 45 yeasts cultures, 8 representatives of genus Saccharomyces, 6 - Torulopsis and 1 - Hansenula), characterized by accumulation of biomass while growing on at high concentrations of TNT and RDX have been selected. Growth in other cultures was significantly inhibited or stopped when concentration of explosives in nutrient medium was increased. It should be noted that in such cases rugosity of the surface of colonies and secondary growth was observed.

Actinomycetes reveal much lower TNT assimilation potential. Only 3 strains (Streptomyces griseus 138A, Streptomyces griseus $241 \mathrm{H}$ and Streptomyces griseus $242 \mathrm{H}$ ) among 90 tested 
strains exposed average growth on the medium containing $0.1 \mathrm{mM}$ TNT. It should be noted that indicated strains were growing more intensively during the presence of $0.5 \%$ starch as cosubstrate.

In the same way actinomycetes exposed lowe RDX assimilation feature. 37 cultures among 90 tested strains were grown on the medium containing $0.1 \mathrm{mM}$ RDX; at $0.5 \mathrm{mM}$ RDX concentration growth ability was exposed by 15 strains of genus Streptomyces (representatives of groups: Ruber, Violaceus, Griseus u Fradia); and at $1.0 \mathrm{mM}$ of RDX concentration neither of cultures of tested actinomycetes survived.

Selected cultures of microorganisms and artificially created consortia composed by some of them were tested in conditions of submerged cultivation on the media containing $0.5 \mathrm{mM}$ TNT. The cultivation was conducted for 3-7 days on shaker (180-200 rpm, at temperature $\left.28-30^{\circ} \mathrm{C}\right)$ in modified Czapek's medium, containing $0.5 \mathrm{mM}$ TNT. Glucose was added as the additional carbon source for the activation of strains metabolism.

According to the results obtained strains: Mucor sp. D1-1, Trichoderma viridae X 1-3 and Trichoderma viridae M 3-3 are themost effective degraders of TNT, decreasing the concentration of the explosive by more than $90 \%$ in 3 days.

From the active bacterial strains, two consortia were composed, which assimilate TNT and at the same time effectively accumulate the biomass (Consortium 1: Pseudomonas sp. $211+$ Pseudomonas sp. R67 + Rhodococcus sp. TNT124; Consortium 2: Pseudomonas sp. 6 Ru56 + Pseudomonas sp. GN32 + Rhodococcus sp.TNT74 + Pseudomonas sp. $211+$ Pseudomonas sp. R67 + Rhodococcus sp. TNT124). The assimilation of TNT by these consortia under submerged cultivation is presented in Fig. 3.

The dynamics of revelation of TNT-nitroreductase activity in cultures of microorganisms, selected according to the results of targeted screening have been studied. The results show that all tested strains form nitroreductase. Almost in all cases this enzyme is induced by the presence of TNT in the cultivation medium, with the exception of Chaetomium $\mathrm{J} 1-4$. The maximum level of nitroreductase activity for this strain was achieved on the 2nd day of cultivation (on 3rd day for Mucor D 1-1). The nitroreductase activity of tested microscopic fungi strains decreases according to the following order:

\section{Aspergillus niger D 35 > Penicillium D T-1 > Aspergillus niger J 3-4 > Mucor D 1-1 $>$ Chaetomium J 1-4 > Trichoderma D 1-1}
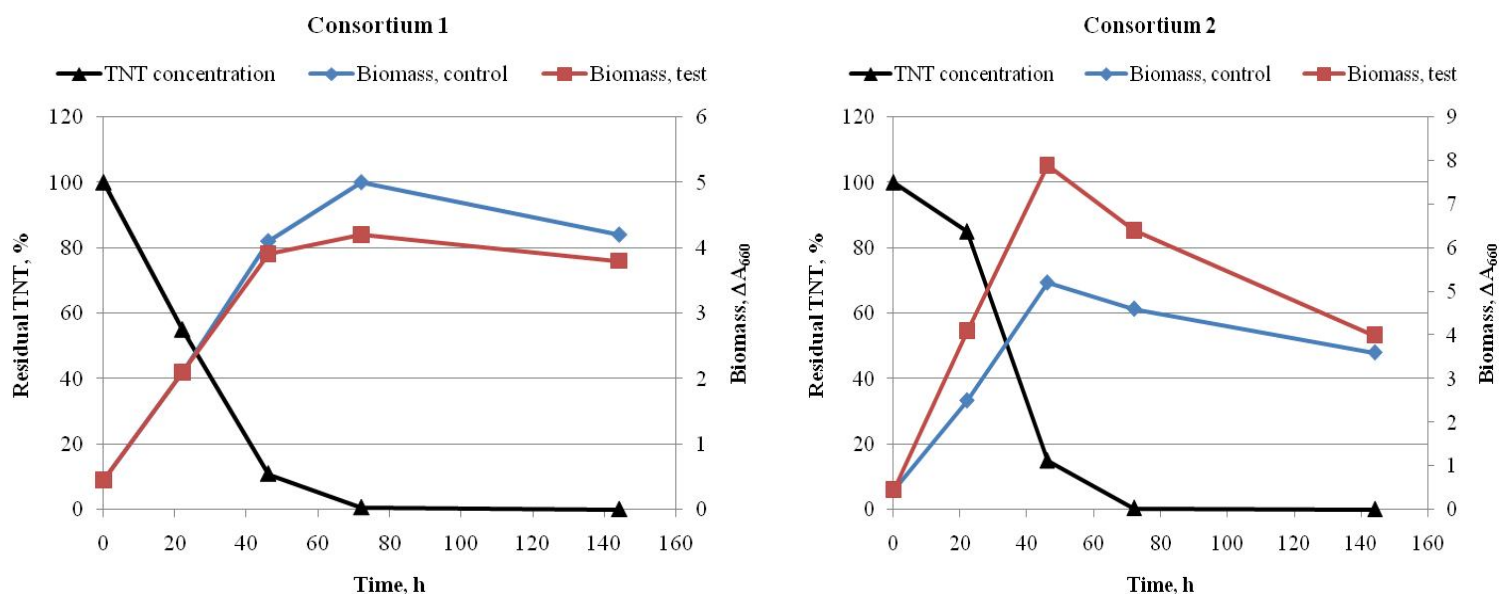

Fig. 3. The assimilation of TNT by bacterial consortia in submerged cultivation.

Consortium 1: Pseudomonas sp. $211+$ Pseudomonas sp. R67 + Rhodococcus sp. TNT124

Consortium 2: Pseudomonas sp. 6 Ru56 + Pseudomonas sp. GN32 + Rhodococcus sp.TNT74 + Pseudomonas sp. $211+$ Pseudomonas sp. R67 + Rhodococcus sp. TNT124 
Comparison nitroreductase activity of 2 cultures from the genus Bacillus showed that strain Bacillus sp. 95 has good ability to grow on TNT containing media and has 4 fold higher nitroreductase activity than Bacillus sp. 92, which is weakly adapted to growth on the explosive. In addition, is observed for Bacillus sp. 95 that incubation on medium containing TNT increased nitroreductase activity 5 fold, whereas for Bacillus sp. 92 the induction is only expressed by burst of enzymatic activity on the 2nd day of cultivation.

Strains Saccharomyces vini 38 and Saccharomyces vini 41 were grown on TNTcontaining medium in aerobic and anaerobic conditions. It has been established that for both cultures the nitroreductase was induced more intensively in the medium without oxygen.

The study of nitroreductase activity accumulation dynamics in strains of Pseudomonas has revealed that the presence of glucose (at $2 \%$ concentration) stimulates induction of enzyme catalyzing reductive transformation of nitro groups during the degradation of TNT.

The TNT-nitroreductase activity was revealed by fungi strains growing on RDXcontaining medium. This indicates that fungi nitroreductase is capable of reducing not only nitro groups of TNT that are substituted in the aromatic ring but also nitro groups that are bound to non aromatic hexahydrotriazine heterocycle in RDX. The maximum of nitroreductase activity was achieved on the $2^{\text {nd }}$ and 3 rd days of cultivation on RDX-containing medium (on 4th day for Aspergillus niger J 3-4). The nitroreductase activity of tested microscopic fungi decreases, according to following order:

\section{Mucor D 1-1 > Aspergillus terreus J 2-3 > Trichoderma viride J 3-1 > Aspergillus niger J 3-4 > Chaetomium J 1-4 > Penicillium sp. G 1}

Similar to microscopic fungi, bacterial strains of genera Pseudomonas, Bacillus, Rhodococcus, as well as yeast cultures grown on RDX-containing medium, produce enzymes that reduces TNT in the presence of NADPH. However, while the cultivation/grown of these microorganisms the effect of induction for bacterial strains was expressed to a lower extent for microscopic fungi.

It must be also noted that the tested microorganisms grow weakly in conditions when RDX is used as the sole carbon source, whereas in the presence of small amount of glucose the majority of tasted strains reveal good growth. The growth potential for these microorganisms decreases according to following order while growing on RDX-containing medium:

\section{Rhodococcus > Pseudomonas $>$ Bacillus}

According to the obtained results, soybean and alfalfa are best phytoremediators for cleaning of soils contaminated with explosives. Among the fungi: Aspergillus niger D 35, Mucor sp. D 1-1 expose the best RDX assimilating potential. The bacterial consortium of genera Rhodococcus and Pseudomonas are serviceable for initiating and effectively leading the remediation process.

Model experiment for remediation of soils polluted with TNT

The model experiments for testing the remediation potential of selected microorganisms and plants for soil remediation and water cleaning were carried out.

\section{Experiment No 1:}

Cleaning object: Red soil $(1 \mathrm{~kg}$ ) artificially polluted with TNT, equal to $62 \mathrm{mg} / \mathrm{kg}$.

Tools for cleaning:

1. Bacterial strain Rhodococcus sp. TNT-74 
2. Bacterial strain Pseudomonas sp. TNT-44

3. Fungi Aspergillus niger J 3-4

4. Fungi Mucor sp. D 1-1

5. Consortium composed of bacterial strains Rhodococcus sp. TNT-74 and Pseudomonas sp. TNT-44.

The incubation was carried out at ambient temperature of $20-25^{\circ} \mathrm{C}$ and illumination. After 30 days of incubation the residual content of TNT was determined in soil samples. The results are presented in Table 3.

Table 3.

Residual content of TNT in samples of polluted soil (Model experiment \#1) after 30 days of incubation. Initial pollution - $62 \mathrm{mg} / \mathrm{kg}$

\begin{tabular}{|l|c|c|}
\hline \multicolumn{1}{|c|}{ Test variant } & $\begin{array}{c}\text { Residual TNT, } \\
\mathrm{mg} / \mathrm{kg}\end{array}$ & $\begin{array}{c}\text { Remediation degree (decrease } \\
\text { of TNT from initial pollution), } \%\end{array}$ \\
\hline $\begin{array}{l}\text { Control (without inoculation of mi- } \\
\text { croorganisms) }\end{array}$ & 44.7 & 28.0 \\
\hline Pseudomonas sp. TNT-44 & 31.0 & 50.0 \\
\hline Rhodococcus sp. TNT-74 & 29.8 & 52.0 \\
\hline Aspergillus niger J 3-4 & 39.7 & 36.0 \\
\hline Mucor sp. D 1-1 & 33.5 & 46.0 \\
\hline $\begin{array}{l}\text { Consortium (Pseudomonas sp. TNT- } \\
\text { 44 +Rhodococcus sp. TNT-74) }\end{array}$ & 25.4 & 59.0 \\
\hline
\end{tabular}

\section{Experiment No 2:}

Cleaning object: Red soil (mass $1 \mathrm{~kg}$ ) artificially polluted with TNT equal to $62 \mathrm{mg} / \mathrm{kg}$.

Tools of cleaning:

1. Soybean ( 25 seedlings on $1 \mathrm{~kg}$ soil)

2. Alfalfa (100 seedlings on $1 \mathrm{~kg}$ soil)

3. Consortium composed with bacterial strains Rhodococcus sp. TNT-74 and Pseudomonas sp. TNT-44.

4. Soybean ( 25 seedlings on $1 \mathrm{~kg}$ soil) and Consortium

5. Alfalfa (100 seedlings on $1 \mathrm{~kg}$ soil) and Consortium.

The incubation was carried out at ambient temperature of $20-25^{\circ} \mathrm{C}$ and illumination. After 15 and 30 days of incubation, residual content of TNT was determined in soil samples. The thin-layer chromatographic (TLC) analysis of methanol extracts from polluted soil samples was carried out. The chromatographic plates were developed with mixture of: benzene: dioxane: acetic acid (90:10:1). The results are presented in Tables 4 and 5. 
Table 4.

Residual content of TNT in samples of polluted Red soil in Model experiment \#2. Initial pollution - $62 \mathrm{mg} / \mathrm{kg}$

\begin{tabular}{|l|c|c|c|c|}
\hline \multicolumn{1}{|c|}{ Test variant } & \multicolumn{2}{|c|}{ Residual TNT, mg/kg } & \multicolumn{2}{|c|}{$\begin{array}{c}\text { Remediation degree (de- } \\
\text { crease of TNT), \% of initial } \\
\text { pollution }\end{array}$} \\
\cline { 2 - 5 } & $\begin{array}{c}\mid c \\
\text { exposure } \\
\text { time 15 } \\
\text { days }\end{array}$ & $\begin{array}{c}\text { exposure } \\
\text { time 30 } \\
\text { days }\end{array}$ & $\begin{array}{c}\text { exposure } \\
\text { time 15 days }\end{array}$ & $\begin{array}{c}\text { exposure } \\
\text { time } 30 \text { days }\end{array}$ \\
\hline $\begin{array}{l}\text { Control (without plants and micro- } \\
\text { organisms) }\end{array}$ & 50.1 & 43.7 & 19.2 & 29.5 \\
\hline $\begin{array}{l}\text { Soybean (without microorgan- } \\
\text { isms) }\end{array}$ & 37.1 & 27.5 & 40.2 & 55.6 \\
\hline Alfalfa (without microorganisms) & 38 & 30.6 & 38.7 & 50.6 \\
\hline Consortium* (without plants) & 43.4 & 27.2 & 30.0 & 56.1 \\
\hline Soybean + Consortium* & 27.9 & 17.7 & 55.0 & 71.5 \\
\hline Alfalfa + Consortium* & 31.5 & 20.4 & 49.2 & 67.1 \\
\hline
\end{tabular}

* Pseudomonas sp. TNT-44 + Rhodococcus sp. TNT-74

Table 5.

TLC analysis of TNT metabolites extracted from samples of polluted Red soil, after 30 days of remediation process (Model experiment \#2)

\begin{tabular}{|l|c|c|c|c|c|}
\hline \multirow{2}{*}{\multicolumn{1}{c|}{ Test variant }} & \multicolumn{5}{c|}{ Metabolites, developed on chromatogram } \\
\cline { 2 - 6 } & $\mathrm{R}_{\mathrm{f}}=0.34$ & $\mathrm{R}_{\mathrm{f}}=046$ & $\mathrm{R}_{\mathrm{f}}=0.61$ & $\mathrm{R}_{\mathrm{f}}=0.74$ & $\mathrm{R}_{\mathrm{f}}=0.87$ \\
\hline TNT (control) & - & - & - & - & + \\
\hline $\begin{array}{l}\text { Soybean (without microorgan- } \\
\text { isms) }\end{array}$ & + & + & - & - & + \\
\hline Consortium* (without plants) & + & + & + & + & + \\
\hline Soybean + Consortium* & - & + & - & - & + \\
\hline
\end{tabular}

* Pseudomonas sp. TNT-44 + Rhodococcus sp. TNT-74

\section{Experiment No 3:}

Cleaning object: Red soil (mass $7 \mathrm{~kg}$ ) artificially polluted with $\left[1-{ }^{14} \mathrm{C}\right] \mathrm{TNT}$.

Initial pollution - $142 \mathrm{mg} / \mathrm{kg}$.

Tools of cleaning: Bacterial consortium composed with bacterial strains Rhodococcus sp. TNT-74 and Pseudomonas sp. TNT-44 and soybean (80 seedlings on $7 \mathrm{~kg}$ soil).

The incubation was carried out at ambient temperature $\left(20-25^{\circ} \mathrm{C}\right)$ and illumination. The results of experiments are presented in Fig. 4 and 5. 


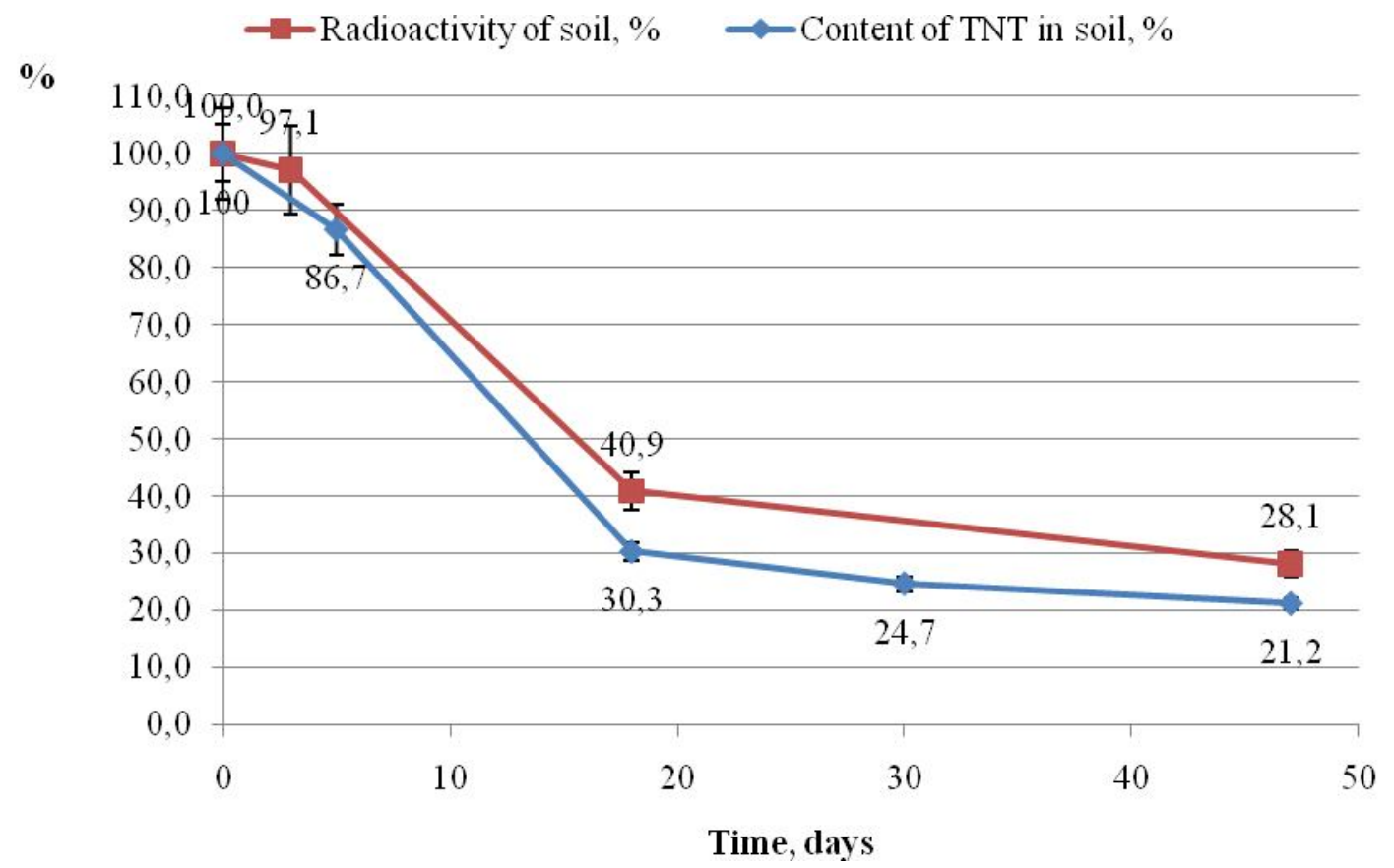

Fig. 4. The dynamics of changing of TNT content in Red soil contaminated with $\left[1-{ }^{14} \mathrm{C}\right]$ TNT during cleaning by soybean and bacterial consortium of Pseudomonas $s p$.

TNT-44 and Rhodococcus sp. TNT-74.

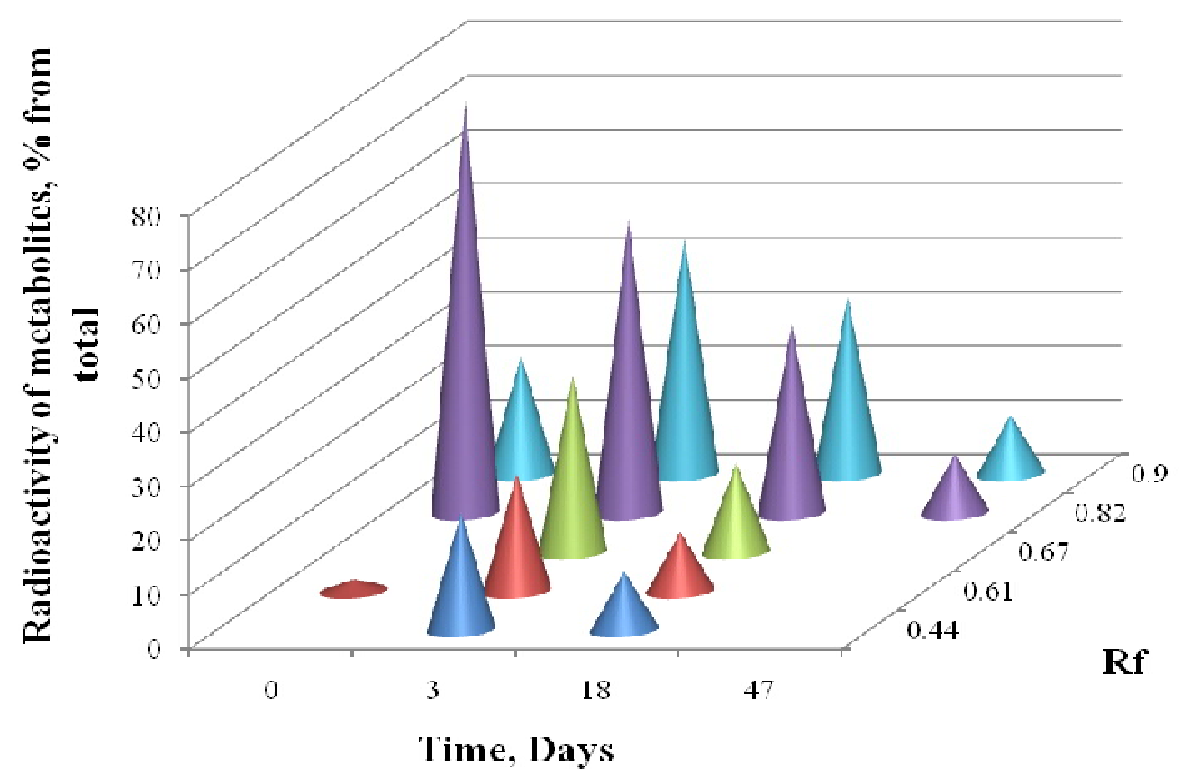

Fig. 5. TLC analyses of $\left[1-{ }^{14} \mathrm{C}\right] \mathrm{TNT}$ metabolites extracted from samples of polluted Red soil on $3^{\text {rd }}, 18^{\text {th }}$ and $47^{\text {th }}$ days during the remediation process

The results of TNT degradation indicate that the aboriginal microflora of soils assimilated up to $30 \%$ of explosive, and the introduced microbial inoculation composed by TNT-degrading 
cultures raises the intensity of bioremediation process additionally by $25-30 \%$. Using plants allows reaching the same result almost twice as faster than in case of applying only microorganisms. Soybean and Ryegrass revealed the highest phytoremediation ability (remediation degree up to $45-50 \%$ ). The highest remediation effects have been detected after sowing soybean in soil treated by consortium containing bacterial strains Pseudomonas sp. TNT-44 and Rhodococcus sp. TNT-74. In such case the remediation degree is increased up to $70-75 \%$ and amount of TNT metabolites in soil is decreased to $20 \%$.

The chromatographic analysis of soils shows that in both cases similar products of TNT transformation are formed. The radioactive metabolites formed as a result of bacterial transformation of $\left[1-{ }^{14} \mathrm{C}\right] \mathrm{TNT}$ are effectively up taken from soil by the plants.

\section{Experiment No 4:}

Cleaning object: Tap water (volume $6 \mathrm{~L}$ ) artificially polluted with radioactive $\left[1-{ }^{14} \mathrm{C}\right] \mathrm{TNT}$ (specific radioactivity $-500 \mathrm{~Bq} / \mathrm{mg}$ ). Concentration of TNT- $0.1 \mathrm{mM}$, total initial radioactivity of polluted water $-210400 \mathrm{~Bq}$.

Tools of cleaning: Bacterial consortium composed by Pseudomonas sp. TNT-44 и Rhodococcus sp. TNT-74 and 12-days-old seedlings of soybean, preliminarily cultivated on pure tap water.

The results presented in Fig. 6 show that in both cases (using plants without and with bacteria) a significant decrease of water pollution level takes place. Intensity of these processes is almost identical. This fact indicates that plants are capable to completely extract almost all metabolites from water, formed as a result of biotransformation $\left[1-{ }^{14} \mathrm{C}\right]$ by bacterial strains.

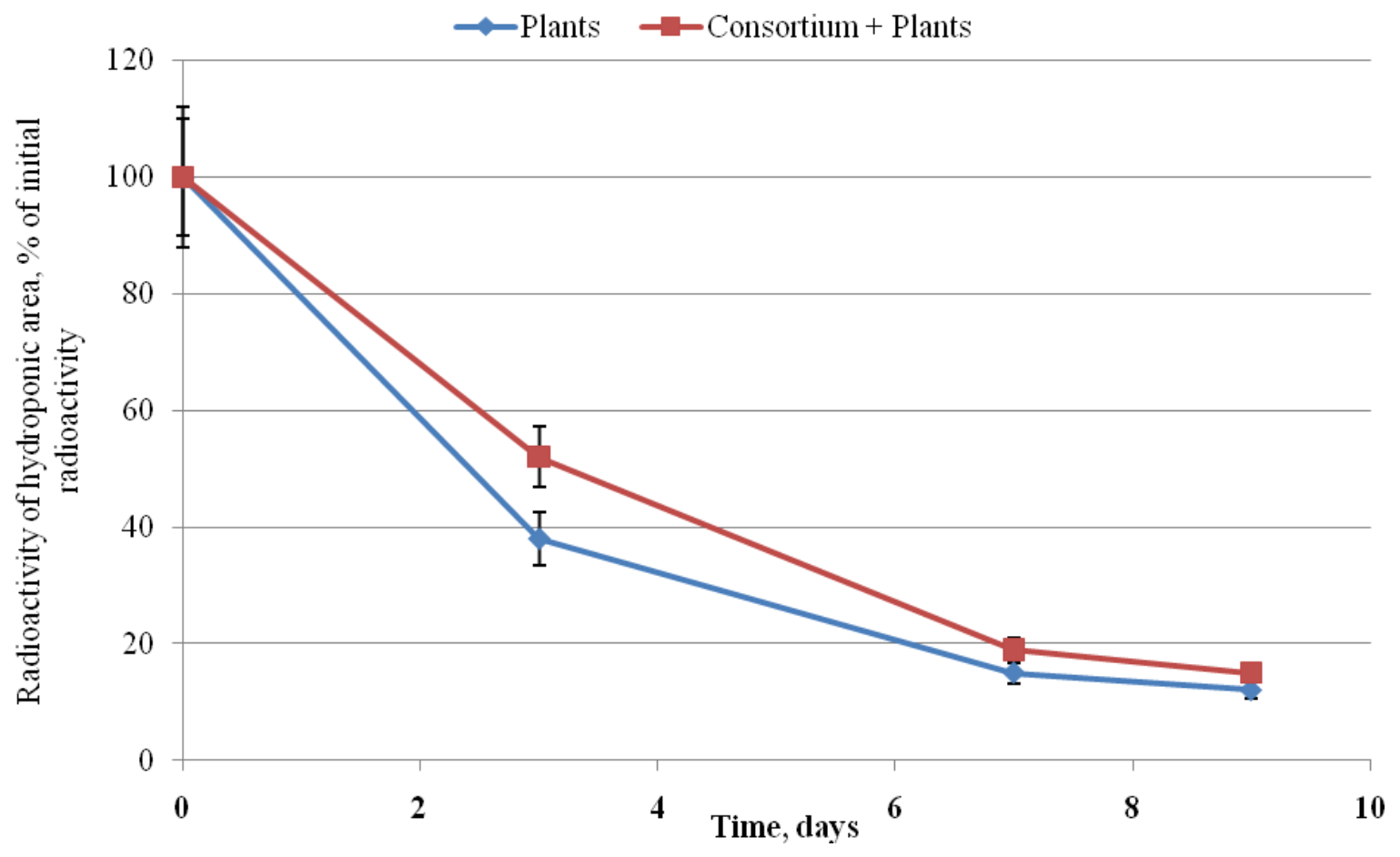

Fig. 6. The dynamics of changing of TNT content in water contaminated with $\left[1-{ }^{14} \mathrm{C}\right]$ TNT during cleaning by soybean and bacterial consortium of strains Pseudomonas sp. TNT-44 and Rhodococcus sp. TNT-74 
Bioutilization of plants after phytoremediation

Research to establish the optimal conditions for bioutilization of plants used in phytoremediation of soils polluted with explosives was carried out. For this task, TNT-degrading cultures of microscopic fungi Trichoderma viride X 1-3, Aspergillus niger J 3-5 and Mucor sp. D 1-1 were cultivated on medium with dried and grinded biomass of aboveground parts of soybean seedlings as a sole carbon source.

The results show that the highest destruction of plant biomass is achieved when $5 \mathrm{~g}$ of soybean biomass was added to $100 \mathrm{ml}$ suspension of microscopic fungi. Research to determine the optimal conditions for bioutilization of plants previously used in phytoremediation of water polluted with $\left[1-{ }^{14} \mathrm{C}\right]$ TNT was carried out. For these aims TNT-degrading cultures of microscopic fungi Aspergillus niger J 3-5 were cultivated on medium with dried and grinded biomass of soybean seedlings (from Experiment \#4) as a sole carbon source. The results are presented in Fig. 7.

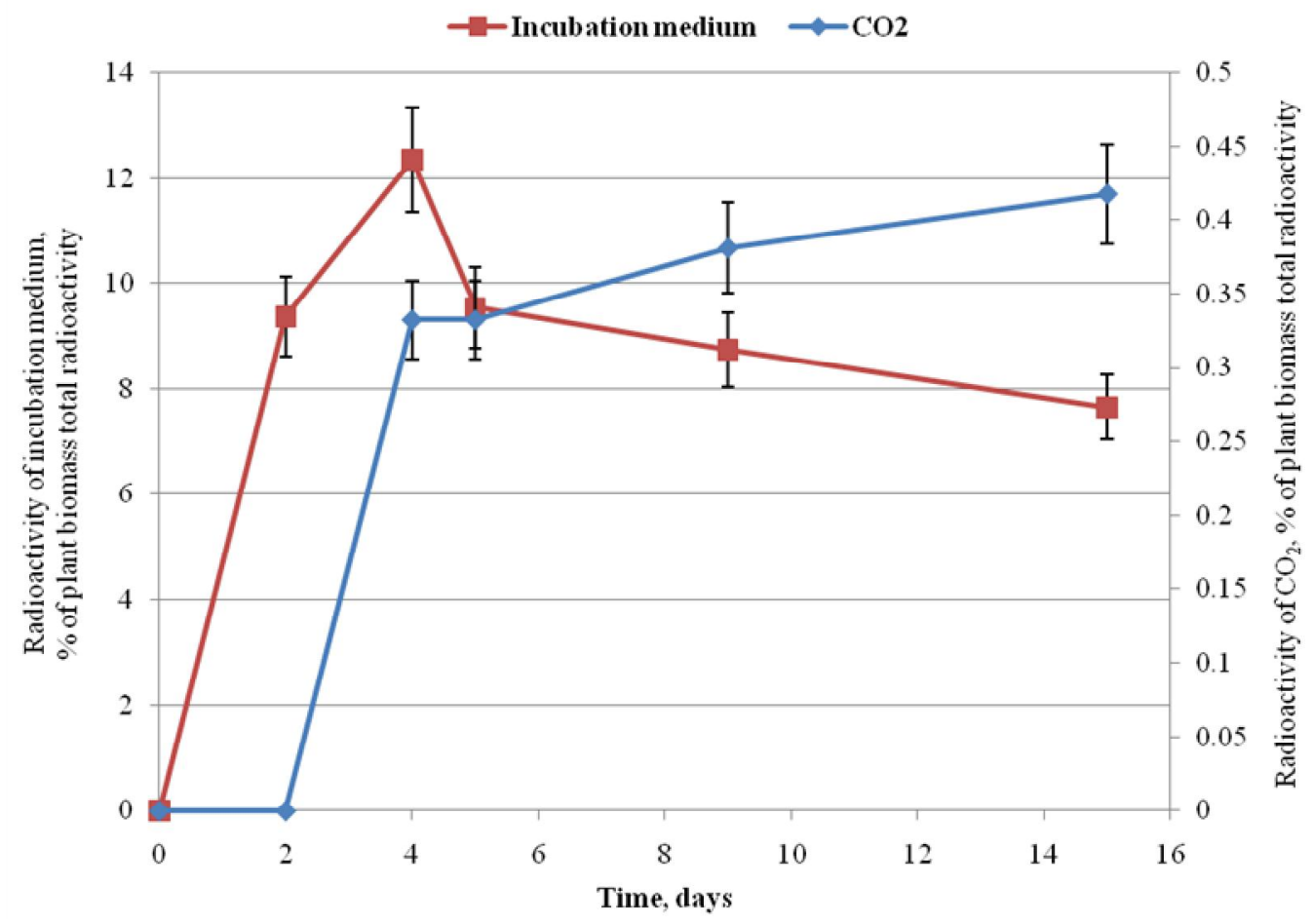

Fig. 7. The dynamics of the radioactivity of incubation medium changing and release of ${ }^{14} \mathrm{CO} 2$ during the utilization of soybean biomass by microscopic fungi Aspergillus niger $\mathrm{J}$ 3-5. Content of incubation medium (g/l): $\mathrm{NaNO}_{3}-0.91 ; \mathrm{KH}_{2} \mathrm{PO}_{4}-0.1 ; \mathrm{MgSO}_{4} \cdot 7 \mathrm{H}_{2} \mathrm{O}-0.05$; $\mathrm{KCl}-0.05 ; \mathrm{FeSO}_{4} \cdot 7 \mathrm{H}_{2} \mathrm{O}-0.02$; and $36.5 \mathrm{~g}$ of soybean biomass with total radioactivity of $178000 \mathrm{~Bq}$ total

The obtained data indicate that during the destruction of biomass of plants by microscopic fungi Aspergillus niger J 3-5 the release of part of labelled TNT and its metabolites from plant biomass takes place. The occurrence of radioactivity in alkaline solution specifies that extracellular enzymes of fungi oxidized TNT and its metabolites to carbon dioxide. TCL 
analysis of incubation medium shows that in cultural liquid 6 compounds with different $R_{f}$ values are presented. Only 2 metabolites (with $R_{f}=0.12$ and $R_{f}=0.15$ ) from them are radioactive (Fig. 8), i.e. they are formed from $\left[1-{ }^{14} \mathrm{C}\right] \mathrm{TNT}$.

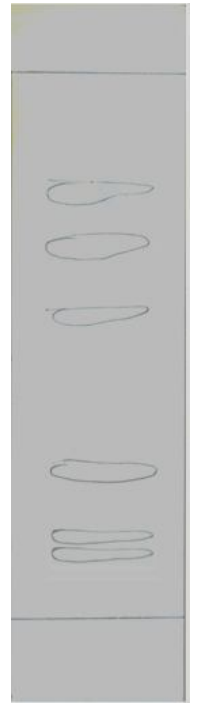

A

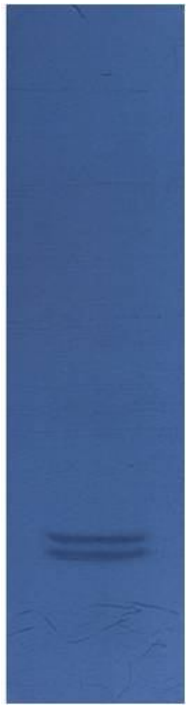

B
Fig. 8. TLC of benzene extract from cultural liquid at the end of the experiment of utilization of soybean biomass by microscopic fungi Aspergillus niger $\mathrm{J} 3-$ 5.

A - Chromatogram;

$B$ - Copy of chromatogram on X-ray film after 45 days exposition.

Apparently, in parallel with the release of intermediates of $\left[1-{ }^{14} \mathrm{C}\right]$ TNT its transformation and further degradation occurs. Analysis of $\left[1-{ }^{14} \mathrm{C}\right]$ TNT metabolites shows that the basic part of TNT is metabolized to fumaric acid as a result of the action of Aspergillus niger $\mathrm{J}$ 3- 5 enzymes.

\section{Conclusions}

Screening of plants according to their potential to assimilate TNT and RDX was carried out. As a result, 3 plant species (soybean, alfalfa and ryegrass), 41 bacterial cultures, 14 strains of microscopic fungi, 3 strains of yeast were selected. Two bacterial consortia for bioconversion of TNT were composed. Selected cultures of microorganisms and consortia were tested in conditions of submerge cultivation on the areas containing $0.5 \mathrm{mM}$ TNT. Optimum conditions of submerge cultivation $(\mathrm{pH}$, temperature, duration of incubation) for selected active strains has been established. Model experiments were carried out for testing selected microorganisms and plants for soil remediation and water cleaning. As a result of the experiments performed for water cleaning, it has been established that 12-days-old soybean seedlings effectively absorb $\left[1-{ }^{14} \mathrm{C}\right]$ TNT from the polluted water and after 8 days approximately 80 $\%$ of clearing effect is reached. It has been shown that that during destruction of biomass of plants by microscopic fungi Aspergillus niger J 3-5 the release of part of labelled TNT and its metabolites from plant biomass and the release of radioactive $\mathrm{CO}_{2}$ takes place.

\section{References}

1. Adamia G., Ghoghoberidze M., Graves D., Khatisashvili G., Kvesitadze G., Lomidze E., Ugrekhelidze D., Zaalishvili G. Absorption, distribution and transformation of TNT in higher plants // Ecotoxicology and Environmental Safety. Vol. 64. 2006. 
2. Aken B. van, Yoon J. M., Just C. L, Schnoor J. L. Metabolism and mineralization of hexahydro-1,3,5-trinitro-1,3,5-triazine inside poplar tissues (Populus deltoides x nigra DN-34) // Environmental Science\&Technology. Vol. 38. 2004.

3. Best E. P. H., Kvesitadze G., Khatisashvili G., Sadunishvili T. Plant processes important for the transformation and degradation of explosives contaminants // Zeitschrift für Naturforschung. Vol. 60. 2005.

4. Best E. P. H., Sprecher S. L., Larson S. L., Fredrickson H. L., Bader D. F. Environmental behavior and fate of explosives from groundwater from the Milan Army Ammunition Plant in aquatic and wetland plant treatments. Uptake and fate of TNT and RDX in plants // Chemosphere. Vol. 39. 1999.

5. Bradford M.M. A rapid and sensitive method for the quantitation of microgram quantities of protein utilizing the trinciple of protein dye binding // Analytical Biochemistry. No 59. 1974.

6. Esteve-Núňez A., Caballero A., Ramos J.L. Biological degradation of 2,4,6-trinitrotoluene // Microbiology and Molecular Biology Reviews. Vol. 65. 2001.

7. Gregory R., Bendall D. The purification and some properties of the polyphenol oxidase from tea (Camellia sinensis L.) // Biochemistry Journal. 1996.

8. Harms H., Bokern M., Kolb M., Bock C. Transformation of organic contaminants by different plant systems // Phytoremediation. Transformation and Control of Contaminants. New Jersey, 2003.

9. Kvesitadze G., Khatisashvili G., Sadunishvili T., Ramsden J.J. Biochemical mechanisms of detoxification in higher plants. Basis of Phytoremediation. Berlin, New York, 2006.

10. Khatisashvili G., Kurashvili M., Gordeziani M. Isolation of plant microsomal fraction and characterization of its oxidative systems // Bulletin of the Georgian Academy of Science. No 152. 1995.

11. Lanzarini G., Pifferi P., Samorani A. Specificty of an o-diphenol oxidase from Prunus avium fruits // Phytochemistry. No 11. 1972.

12. Oh B., Sarath G., Drijber R. A., Comfort S. D. Rapid spectrophotometric determination of 2,4,6-trinitrotoluene in a Pseudomonas enzyme assay // Microbiological Methods. Vol. 42. 2000.

13. Robidoux P. Y., Hawari J., Thiboutot S., Ampleman G., Sunahara G. I. Acute toxicity of 2,4,6-trinitrotoluene in earthworm (Eisenia andrei) // Ecotoxicology and Environmental Safety. Vol. 44. 1999. 